\title{
CERITA RAKYAT BERBASIS MOBILE UNTUK ANAK SEKOLAH DASAR
}

\author{
I Nyoman Laba Jayanta1, Ketut Susiani² \\ ${ }^{1}$ Jurusan Pendidikan Guru Sekolah Dasar, Universitas Pendidikan Ganesha \\ 2Jurusan Pendidikan Guru Sekolah Dasar, Universitas Pendidikan Ganesha
}

\begin{abstract}
Abstrak
This research aimed at developing a mobile-based folklore with local wisdom inserted for elementary school students in which the language used is Balinese. The present research was applying System Development Life Cycle (SDLC) research method. The study underwent five steps, that is, Analysis, Design, Implementation, Testing, and Evaluation. The first step of this research was need analysis of the application. In this step, the need analysis of content application and application development was done. The next step was application design including flowchart design and storyboard. The steps of development was using application design plan. In this step, the result was Balinese folklore application with local wisdom inserted. To test the function of this application, an application test was done by applying black box method. This evaluation was conducted by involving teacher and elementary school students at SDN 3 Banyuning. The result of evaluation showed that it was found 20 out of 25 students liked this folklore application with local wisdom inserted.
\end{abstract}

\author{
Keywords: \\ local wisdom, \\ folklore, \\ mobile application
}

\section{Pendahuluan}

Setiap siswa memiliki kemungkinan untuk berhadapan dengan berbagai kesulitan-kesulitan, kendala dan tekanan psikologis (stres) dalam melaksanakan tugas-tugas akademiknya serta tugas-tugas berdasarkan fase perkembangannya. Begitu juga dengan siswa sekolah dasar yang mengalami kesulitan dalam berbahasa bali. Sejak beberapa tahun yang lalu bahasa daerah diajarkan di sekolah-sekolah, baik sebagai muatan lokal maupun sebagai mata pelajaran. Kedudukan pengajaran bahasa daerah di sekolah tidak terlepas dari pandangan terhadap kedudukan dan fungsi bahasa daerah itu sendiri. Hingga sekarang, kedudukan dan fungsi bahasa daerah itu diletakkan dalam tautan kedaerahan dan bukan dalam tautan nasional Rusyana (dalam putrayasa 2005). Berdasarkan uraian tersebut, kiranya perlu dilakukan pembaharuan dalam memandang bahasa daerah, yaitu bahasa daerah dihargai sebagai kekayaan nasional yang dapat menjadi sumber kekuatan dan kreativitas dalam kehidupan bangsa. Pengajaran bahasa daerah, dalam pandangan tersebut, mengemban kedudukan dan fungsi bagi kepentingan seluruh bangsa.

Tantangan terbesar yang dihadapi masyarakat Bali saat ini adalah kemampuan menjaga, mewariska, dan melestarikan kearifan-kearifan lokal. Globalisasi dan modernisasi telah membawa membawa nilai-nilai baru ke dalam tatanan masyarakat yang tentunya berpengaruh terhadap nilai-nilai lokal yang ada (Suwardani, 2015). Seperti halnya observasi yang dilakukan oleh Aliansi Peduli Bahasa Bali yang menemukan bahwa anak-anak sekolah dasar saat ini tidak terbiasa menggunakan Bahasa Bali baik dalam pergaulan di sekolah maupun di rumah. Hal ini merupakan kondisi yang saat serius dan perlu mendapat perhatian untuk melestarikan Bahasa Bali dan juga nilai-nilai kearifan lokal lainya sebagai aset budaya Bali. Penghapusan Bahasa Bali dari kurikulum juga sempat menjadi kontroversi karena dianggap tidak sejalan dengan usaha pelestarian aset budaya Bali. Suwija, (2012) menyatakan bahwa pembelajaran bahasa Bali sangat kental dengan nilai-nilai budaya Bali yang dijiwai oleh Agama Hindu dan banyak mengandung nilainilai karakter bangsa. Secara implisit kondisi ini menujukan bahwa jika nilai-nilai budaya Bali atau local gunius tidak dipertahankan maka secara otomatis salah satu nilai karakter bangsa ikut hilang.

Haryati Soebadio menyatakan bahwa local genius adalah juga cultural identity, identitas atau kepribadian budaya bangsa yang menyebabkan bangsa tersebut mampu menyerap dan mengolah kebudayaan asing sesuai watak dan kemampuan sendiri (Ayatrohaedi, 1986). Bali sebagai daerah yang terkenal akan kekayaan budayanya memiliki nilai kearifan dalam konten lokal-nya (localcontent). Keragaman nilai kearifan mencakup berbagai hal, dari etika atau tata susila hingga pelaksanaan upacara adat yang bisa bertahan hingga saat ini.

\footnotetext{
* Corresponding author.

E-mail Addresses: laba.jayanta@undiksha.ac.id (I Nyoman Laba Jayanta)
} 
Penyampaian nilai-nilai itu biasa disampaikan secara lisan, namun banyak juga yang didokumentasikan dengan baik dalam karya sastra. Karya sastra yang cukup banyak digunakan dalam penyampaian nilai kearifan lokal adalah Lontar Tantri Carita. Lontar ini pada awalnya berbahasa Kawi, namun kini sudah diterjemahkan dalam Bahasa Bali, Bahasa Indonesia, bahkan Bahasa Inggris. Lontar Tantri Carita menyampaikan kearifan lokal melalui fabel, atau yang biasa dikenal sebagai cerita rakyat yang pemeran utamanya sebagian besar binatang. Penyampaian pesan dengan bercerita yang dalam terminologi Barat dikenal sebagai storytelling, menurut berbagai penelitian memang efektif dalam penyampaian pesan, khususnya bagi anak-anak. Guru sebagai pendidik yang memiliki tugas diantaranya mendidik peserta didik juga harus mampu menyampaikan pesan muatan lokal dalam pembelajaran, mengingat diera globalisasi persaingan sumber daya manusia (SDM) Indonesia akan dihadapkan dengan SDM dari negara-negara lainnya Khususnya di Asean.

Sejalan dengan itu, Group (2003) mengemukakan bahwa untuk sukses di abad 21, lembaga pendidikan harus mempersiapkan peserta didiknya untuk memasuki dunia kerja yang berbeda melalui penghargaan terhadap inovasi, imajinasi, kreativitas dan komunikasi. Terkait dengan itu, Group mengidentifikasikan empat kelompok keterampilan yang dibutuhkan oleh peserta didik meliputi (1) melek digital, kemampuan menguasai teknologi informasi komunikasi (2) pemikiran inventif, kemampuan untuk berpikir di luar kotak kelaziman, yang mencakup kemampuan beradaftasi dan mengelola komfleksitas, self direction, rasa ingin tau, kreatifitas, berani mengambil resiko, sebagai prasyarat keberhasilan abad 21, yang meliputi kemampuan ketrampilann menyusun skala prioritas, perencanaan dan pengelolaan, terampil dalam memanfaatkan teknologi, menghasilkan produk yang berkualitas dan relevan dengan kebutuhan. Oleh sebab itu perlu kiranya mengkemas pembelajaran dengan sebuah media berbasis kearifan lokal melalui cerita rakyat dengan memanfaatkan teknologi yang merupakan sebuah kebutuhan yang tidak bisa dihindari.

Studi oleh I Made Marthana Yusa dan I Putu Purwa Andika (2013) menunjukkan bahwa menyampaikan muatan lokal melalui animasi 3 dimensi membantu siswa mengenal budaya dan nilai kearifan lokal serta muatan lokal dalam cerita rakyat. Hal senada juga disampaikan dalam studi Eka Nurjanah (2015) menunjukkan bahwa pembelajaran yang dikemas menggunakan teknologi yaitu berupa e-book dapat membantu siswa meringankan dan mempermudah dalam penyampaian dan meningkatkan hasil pembelajaran melalui cerpen berbasis muatan lokal.

Perkembangan teknologi dewasa ini telah membawa perubahan dalam metode pembalajaran dan pendidikan. Kemajuan teknologi juga telah membawa perubahan pada pola kehidupan anak-anak saat ini, dalam perkembanganya sejak usia dini anak-anak telah terbiasa menggunakan teknologi gadget. Saat ini banyak aplikasi yang diciptakan untuk membantu proses pembelajaran, namun dari hasil penelusuran masih sedikit aplikasi yang dikembangkan yang memuat nilai-nilai kearifan lokal khususnya kearifan lokal Bali. Oleh karena itu, melalui penelitian ini berupaya memadukan antara kemajuan teknologi, serta kebiasaan anak-anak terhadap teknologi dengan mengemas nilai-nilai kearifan lokal ke dalam aplikasi cerita rakyat dengan Bahasa Bali sebagai bahasa pengantarnya.

\section{Metode}

Metodologi yang digunakan untuk mengembangkan aplikasi cerita rakyat berbasis mobile ini adalah Sistem Development Life Cycle (SDLC). SDLC adalah suatu pendekatan yang memiliki tahap atau bertahap untuk melakukan analisa dan membangun suatu rancangan sistem dengan menggunakan siklus yang lebih spesifik terhadap kegiatan pengguna (Kendall \& Kendall, 2006). Selain itu, Sistem Development Life Cycle (SDLC) adalah sebuah proses memahami bagaimana Sistem Informasi dapat mendukung kebutuhan bisnis, merancang sistem, membangun sistem, dan memberikannya kepada pengguna (Dennis, Wixom, \& Roth, 2012). Sistem Development Life Cycle (SDLC) juga merupakan pusat pengembangan sistem informasi yang efisien. SDLC terdiri dari 5 (lima) langkah yaitu, Analysis, Design, Implementation, Testing, dan Evaluation. Adapun tahap pengembangan aplikasi dapat dilihat pada gambar 1. 


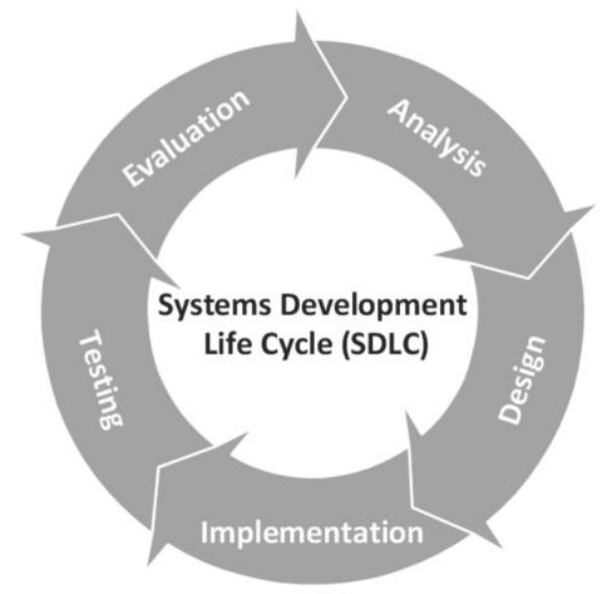

Gambar 1. Tahap pengembangan perangkat lunak dengan SDLC

Populasi penelitian dalam penelitian ini adalah para guru dan siswa kelas V pada SD No 3 Banyuning. Kegiatan uji validitas media (aplikasi) melibatkan (1) ahli bahasa bali dan (2) ahli media, sebagai penilai (pemberi pertimbangan) terhadap rancangan prototype model. Selanjutnya uji coba media terbatas (skala kecil) dilakukan dengan metode eksperimen akan melibatkan guru dan siswa.

\section{Hasil dan Pembahasan}

\section{Analisis Kebutuhan}

Tahap analisis dilakukan untuk mengidentifikasi kebutuhan yang diperlukan untuk mengembangkan aplikasi mobile cerita rakyat. Berdasarkan tahap analisis, untuk mengembangkan aplikasi dibutuhkan hal-hal sebagai berikut:

a. Kebutuhan Cerita Rakyat

Dalam tahap implementasi dibutuhkan cerita rakyat bali yang nantinya akan diimplementasikan ke aplikasi mobile. Cerita dikumpulkan dari hasil studi pustaka yang dilakukan dan didapatkan beberapa cerita bali sebagai sampel penelitian antara lain: a) men sugih dan men tiwas, b) $i$ belog, c) naga basukih, 3) ni bawang teken ni kesuna, 4) siap selem, dimana keseluruhan cerita tersebut nantinya akan diimplementasikan pada aplikasi mobile.

b. Kebutuhan Perangkat

Pengembangan aplikasi cerita rakyat membutuhkan perangkat keras (hardware) dan perangkat lunak (software).

1) Hardware

Untuk melakukan uji coba aplikasi dibutuhkan perangkat handphone dengan sistem operasi android, dengan syarat minimal perangkat keras RAM 512MB. Untuk membuat aplikasi dibutuhkan perangkat keras berupa PC (Personal Computer) dengan spesifikasi: 1) Intel Pentium i3; 2) Misrosoft Windows 7 atau yang terbaru; 3) RAM 2GB; 4) Free 6 GB hardisk untuk instalasi software; 5) 1024x768 display 16-bit color.

\section{2) Software}

Perangkat lunak yang diperlukan untuk mengembangan aplikasi ini adalah: 1) Ionic Lab; 2) Browser Internet; 3) Adobe Photoshop; 4) Text Editor; 5) Node.js; 6) Java runtime envirotment; 7) Android SDK.

\section{Desain}

Melalui analisis kebutuhan di bangun sebuah desain aplikasi mobile cerita rakyat, desain tersebut berupa desain flowchat dan desain storyboard.

a. Desain Flowchat

Desain flowchat dalam pengembangan aplikasi mobile bertujuan untuk menggambarkan alur proses sistem di dalam program. Flowchat cerita rakyat dapat dilihat pada gambar 2. 


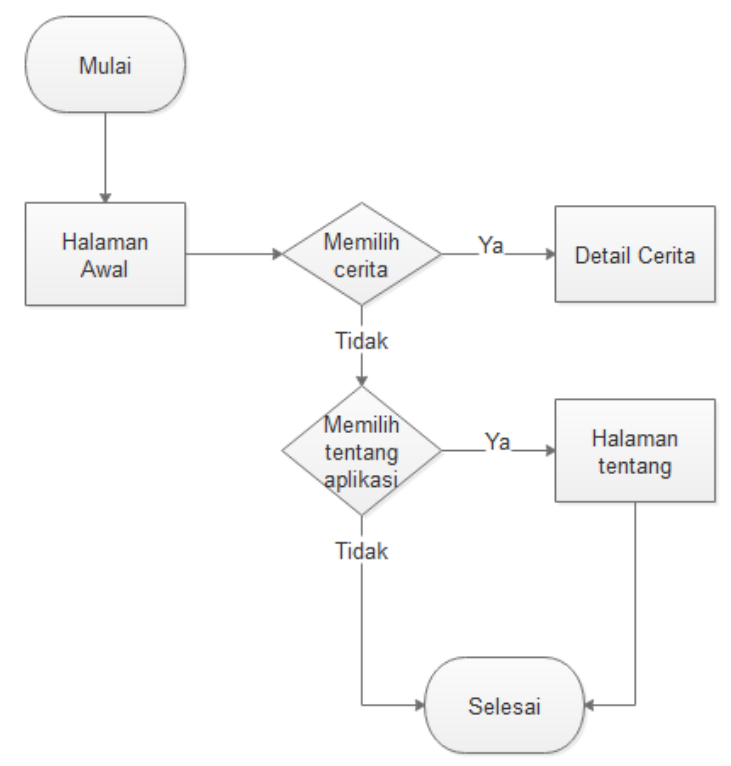

Gambar 2. Flowchat

b. Desain Storyboard

Hasil analisis kebutuhan kemudian digambarkan menjadi sketsa demi memudahkan proses realisasi aplikasi mobile cerita rakyat. Berikut adalah storyboard dari aplikasi cerita rakyat yang dikembangkan. Adapun storyboard aplikasi dapat dilihat pada tabel 1.

Table 1 Storyboard Aplikasi

\begin{tabular}{|c|c|}
\hline Sketsa & Keterangan \\
\hline 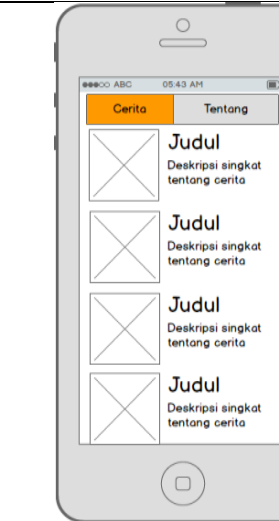 & $\begin{array}{l}\text { Halaman Utama } \\
\text { Halaman utama menampilkan dua menu } \\
\text { aplikasi yaitu menu cerita dan tentang. } \\
\text { Menu cerita menampilkan daftar cerita } \\
\text { yang terdapat dalam aplikasi. Menu } \\
\text { tentang menampilkan halaman deskripsi } \\
\text { mengenai aplikasi. Untuk membaca } \\
\text { cerita, user dapat memilih cerita dengan } \\
\text { menglik judul ataupun gambar dalam } \\
\text { daftar cerita. Saat cerita diklik maka } \\
\text { detail cerita akan ditampilkan. }\end{array}$ \\
\hline \multicolumn{2}{|c|}{ Gambar 3. Daftar Cerita } \\
\hline 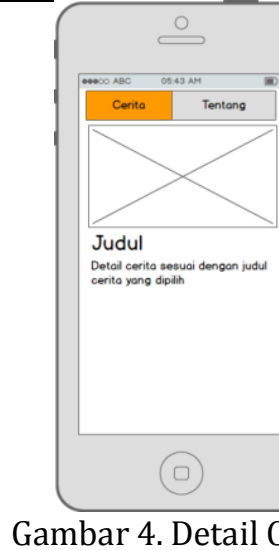 & $\begin{array}{l}\text { Halaman Detail Cerita } \\
\text { Halaman ini menampilkan detail cerita } \\
\text { yang dipilih oleh user. }\end{array}$ \\
\hline
\end{tabular}




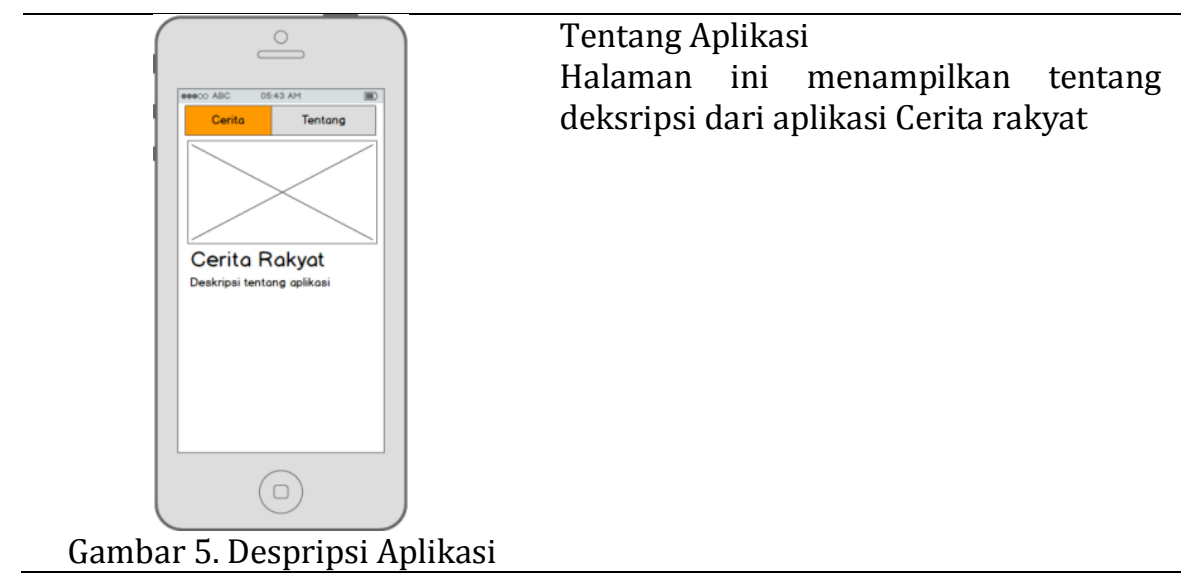

\section{Pengembangan}

Tahap selanjutnya dalam pengembangan aplikasi cerita rakyat adalah implementasi dari desain flowchat dan storyboard. Dalam tahap pengembangan merealisasikan interface atau tampilan dari produk. Dalam membuat interface menggunakan Ionic Lab dengan Ionic Framework dan menggunakan Bahasa Pemrograman HTML dan JavaSript.

a. Source Code Aplikasi

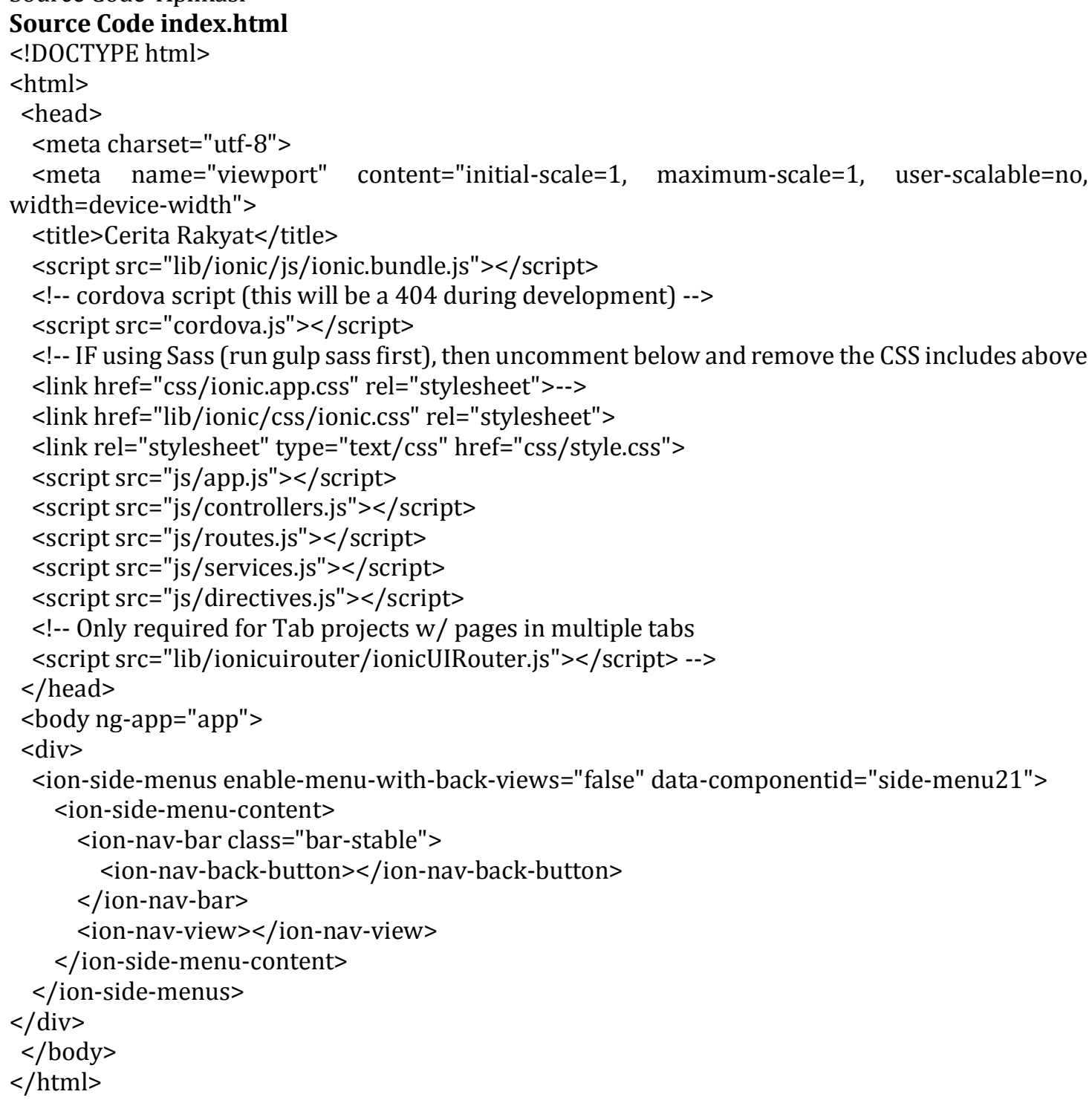


b. Interface Aplikasi

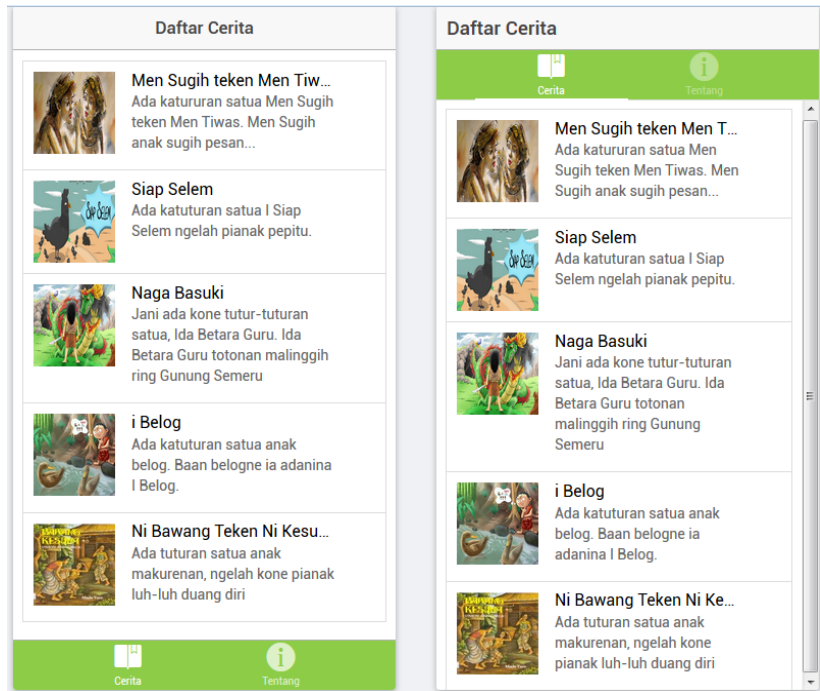

Gambar 6. Tampilan Daftar Cerita

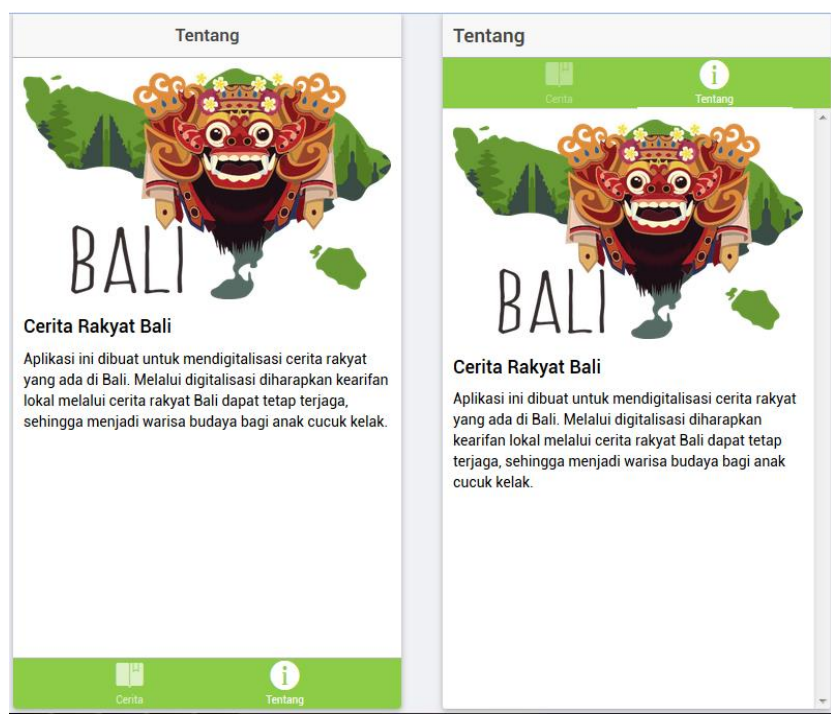

Gambar 7. Tentang Aplikasi Cerita Rakyat

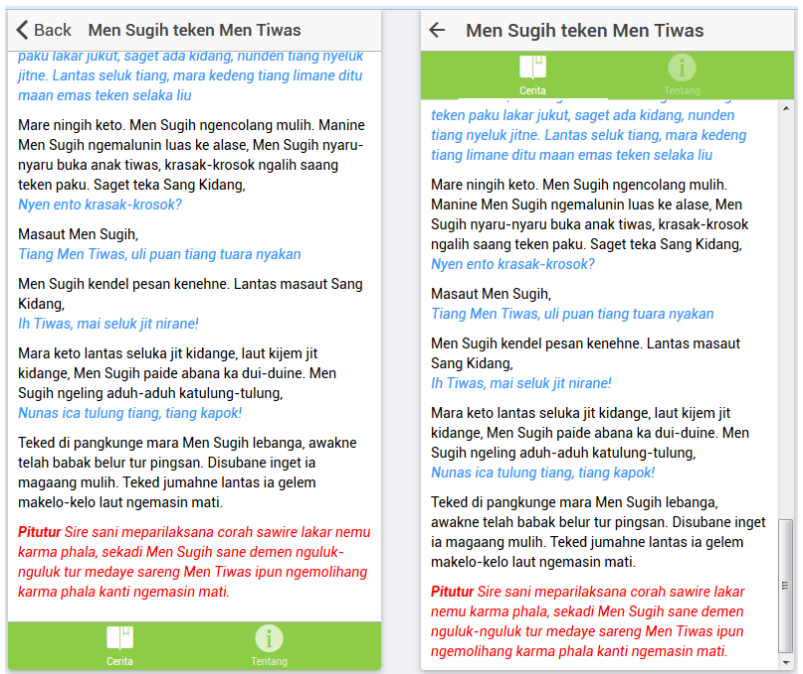

Gambar 8. Nilai Moral dalam Cerita 


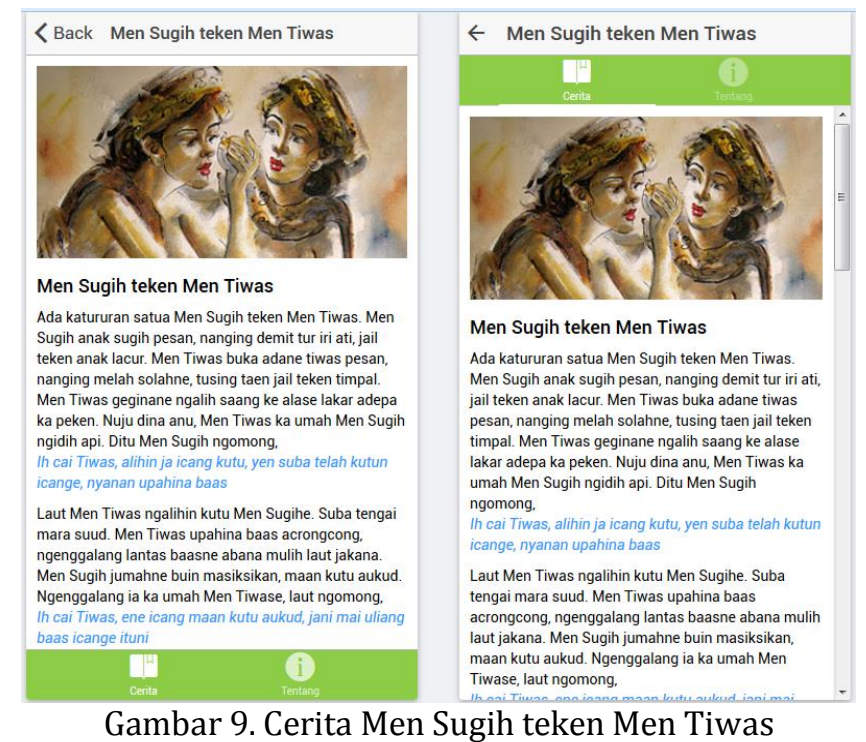

\section{Pengujian Aplikasi}

Pengujian aplikasi dilakukan setelah tahap implementasi sistem selesai dilakukan. Pengujian aplikasi dilakukan untuk memastikan apakah aplikasi sudah berfungsi dengan benar. Tahap uji coba dilakukan sebelum aplikasi digunakan oleh pengguna akhir atau end user. Pada penelitian ini tahap uji coba dilakukan dengam metode black box. Metode black box menggunakan metode pengujian logika dari program yaitu per kasus atau masalah yang diajukan dan dari pengujian ini hasilnya adalah tidak terdapat kesalahan-kesalahan kode program dari aplikasi. Berikut adalah metode pengujian yang dilakukan pada aplikasi mobile cerita rakyat.

\section{Testing Halaman Utama}

Pengujian ini dilakukan untuk memastikan aplikasi dapat berjalan dengan baik saat user membuka aplikasi. Saat user membuka aplikasi, aplikasi menampilkan halaman utama dengan daftar cerita rakyat. Berikut adalah hasil pengujian.

Tabel 2. Hasil Pengujian Halaman Utama

\begin{tabular}{clll}
\hline Kelas Uji & \multicolumn{1}{c}{ Skenario Uji } & \multicolumn{1}{c}{ Hasil yang diharapkan } & \multicolumn{1}{c}{ Kesimpulan } \\
\hline & User memilih icon & Aplikasi cerita rakyat berjalan & {$[\sqrt{]}$ Berhasil } \\
& aplikasi cerita rakyat & dengan baik dan menampilan & {$[$ ] Tidak } \\
Halaman & pada daftar aplikasi & halaman utama dengan daftar & berhasil \\
Utama & di perangkat mobile & cerita rakyat & \\
\cline { 2 - 5 } & User memilih tombol & Aplikasi dapat tertutup & {$[\sqrt{]}$ Berhasil } \\
& keluar & & {$[$ ] Tidak berhasil } \\
\hline
\end{tabular}

\section{Testing Detail Cerita}

Pengujian ini dilakukukan untuk menguji apakah aplikasi dapat menampilkan detail cerita saat user memilih cerita pada halaman utama. Berikut adalah hasil pengujian aplikasi.

Table 3. Hasil Pengujian Halaman Detail Cerita

\begin{tabular}{|c|c|c|c|}
\hline Kelas Uji & Skenario Uji & Hasil yang diharapkan & Kesimpulan \\
\hline \multirow[b]{2}{*}{$\begin{array}{l}\text { Halaman } \\
\text { Detail Cerita }\end{array}$} & $\begin{array}{l}\text { User memilih cerita } \\
\text { dengan mengklik } \\
\text { salah satu judul pada } \\
\text { daftar cerita }\end{array}$ & $\begin{array}{l}\text { Saat user memilih judul cerita } \\
\text { pada daftar cerita aplikasi akan } \\
\text { menampilkan detail cerita sesuai } \\
\text { dengan cerita yang dipilih }\end{array}$ & $\begin{array}{l}{[\sqrt{]}] \text { Berhasil }} \\
\text { [ ] Tidak berhasil }\end{array}$ \\
\hline & $\begin{array}{l}\text { User memilih } \\
\text { kembali untuk } \\
\text { kembali ke halaman } \\
\text { utama daftar cerita }\end{array}$ & $\begin{array}{l}\text { Saat user memilik tombol } \\
\text { kembali, aplikasi akan } \\
\text { mengarahkan halaman aplikasi ke } \\
\text { menu utama aplikasi dan } \\
\text { menampilkan daftar cerita }\end{array}$ & $\begin{array}{l}{[\sqrt{]} \text { Berhasil }} \\
\text { [ ] Tidak berhasil }\end{array}$ \\
\hline
\end{tabular}




\section{Testing Halaman Tentang Aplikasi}

Pengujian ini dilakukan untuk mengetahui apakah aplikasi dapat merfungsi dengan benar saat user memilih menu informasi tentang aplikasi. Berikut adalah hasil pengujian aplikasi.

Table 4. Hasil Pengujian Halaman Tentang Aplikasi

\begin{tabular}{|c|c|c|c|}
\hline Kelas Uji & Skenario Uji & Hasil yang diharapkan & Kesimpulan \\
\hline \multirow{2}{*}{$\begin{array}{l}\text { Halaman } \\
\text { Tentang } \\
\text { Aplikasi }\end{array}$} & $\begin{array}{l}\text { User memilih menu } \\
\text { Tentang aplikasi }\end{array}$ & $\begin{array}{l}\text { Saat user memilih menu Tentang, } \\
\text { aplikasi akan menampilkan } \\
\text { informasi detail dari aplikasi } \\
\text { cerita rakyat }\end{array}$ & $\begin{array}{l}{[\sqrt{ }] \text { Berhasil }} \\
{[] \text { Tidak }} \\
\text { berhasil }\end{array}$ \\
\hline & $\begin{array}{l}\text { User memilih } \\
\text { kembali untuk } \\
\text { kembali ke halaman } \\
\text { utama daftar cerita }\end{array}$ & $\begin{array}{l}\text { Saat user memilik tombol } \\
\text { kembali, aplikasi akan } \\
\text { mengarahkan halaman aplikasi } \\
\text { ke menu utama aplikasi dan } \\
\text { menampilkan daftar cerita }\end{array}$ & $\begin{array}{l}{[\sqrt{]}] \text { Berhasil }} \\
\text { [ ] Tidak } \\
\text { berhasil }\end{array}$ \\
\hline
\end{tabular}

\section{Evaluasi Aplikasi}

Setelah dilakukan pengujian aplikasi melalui metode black box untuk mengetahui fungsionalitas sistem dapat bekerja dengan baik dan sesuai tujuan penelitian, selanjutnya dilakukan evaluasi aplikasi dengan pengujian oleh user. Evaluasi ini dilakukan untuk mengetahui respon user terhadap penggunaan aplikasi cerita rakyat ini. Evaluasi aplikasi dilakukan dengan melibatkan guru dan siswa SD No 3 Banyuning. Dari hasil evaluasi didapatkan data 20 dari 25 orang siswa menyukai aplikasi ini dan mengharapkan lebih banyak cerita lagi pada aplikasi ini, sedangkan 5 orang lainya mengatakan biasa saja. Berdasarkan hasil wawancara dengan guru dan pengamatan langsung, ada beberapa saran yang didapatkan antara lain: perlu adanya penambahan cerita berupa audio sehingga user dapat memilih mendengarkan cerita atau membaca cerita, user juga mengaharapkan adanya animasi sehingga cerita menjadi lebih menarik.

\section{Simpulan}

Penelitian ini telah menghasilkan aplikasi cerita rakyat berbasis teknologi mobile. Tahap awal penelitian yang dilakukan dalam membangun aplikasi cerita rakyat adalah analisis kebutuhan sistem, tahap analisis dilakukan dua tahap, yaitu tahap pertama analisis konten sistem dan tahap kedua analisis kebutuhan perangkat pengembangan sistem dari sisi hardware dan software. Selanjutnya setelah tahap analisis dilanjutkan dengan tahap perancangan flowchart, storyboard sistem dan rancangan interface. Setelah tahap ini selesai dilanjutkan tahap berikutnya yaitu implementasi aplikasi dengan menggunakan Bahasa pemrograman Javasript, HTML, dan Andorid. Tahap akhir dari pengembangan aplikasi mobile cerita rakyat adalah pengujian dan evaluasi aplikasi. Pada tahapan pengujian didapatkan bahwa semua fitur aplikasi sudah memenuhi kebutuhan fungsional aplikasi seperti menampilkan daftar cerita dan detail dari cerita. Evaluasi sistem dilakukan dengan melibatkan guru dan siswa di SD No 3 Banyuning, dari hasil evaluasi didapatkan data 20 dari 2 orang siswa menyatakan menyukai aplikasi ini sedangkan 5 orang lainya menyatakan biasa saja.

Berdasarkan hasil wawancara dengan guru dan siswa didapatkan beberapa saran untuk pengembangkan aplikasi, siswa maupun guru mengharapakan adanya fitur audio dengan demikian mereka mendapatkan pilihan untuk mendengarkan atau membaca cerita. Penambahan animasi juga diharapakan untuk membuat aplikasi menjadi lebih menarik.

\section{Daftar Rujukan}

Ayatrohaedi. 1986. Kepribadian Budaya Bangsa (local genius). Jakarta: Pustaka Jaya.

Danandjaja, James. 2007. Folklor Indonesia, Ilmu Gosip, Dongeng, dan lain-lain. Jakarta: Pustaka Utama Grafiti.

Dennis, A., Wixom, B. H., \& Roth, R. M. (2012). System Analysis and Design. United States of America: Wiley. Eiseman Jr, Fred B. 1990. Bali: Sekala \& Niskala. Singapore: Periplus

Eka Nurjanah. 2015. Pengembangan E-Book Interaktif pada Materi Menyimak Unsur-unsur Intrinsik Cerpen Berbasis Kearifan Lokal Pangkalan Bun pada Siswa XI SMA Negeri 1 Kumai. Jurnal NOSI. Vol 3 Nomor 3.

Gregory, R. J. 2000. Psykological Testing History,Principles and Application.Boston: Allyn and Bacon 
Group, Metiri and Ncrel. 2003. En Gauge 21 st Century Skills: Literacy in the digital age. Napierville, IL and Los Angeles, CA: NCREL and Metiri.

Ida Bagus Putrayasa. Profil Pengajaran Bahasa Daerah (BALI) di SD, SLTP, dan SMU Kabupaten Buleleng. Jurnal JPP IKIP. Edisi khusus XXXVIII

Imron, Ali. 2011. Riset Berbasis Kearifan Lokal Menuju Kemandirian Bangsa. Proceeding Forum Ilmiah Nasional Program Pascasarjana UMY, 24 Desember 2011.

Kendall, K.E., Kendall, J.E., 2006. Analisis dan Perancangan Sistem Edisi ke-5. Jakarta: Indeks.

Safaat.2012.Pemrograman Aplikasi Mobile Smartphone dan Tablet Berbasis Android. Bandung Informatika

Sarmadi, L.G. 2009. Kajian Strukturalisme Dan Nilai Edukatif Dalam Cerita Rakyat Kabupaten Klaten. Surakarta: Universitas Sebelas Maret

Sedyawati, Edi dkk. 2004. Sastra Melayu Lintas Daerah. Jakarta: Pusat Bahasa.

Suwardani, N. P. (2015). Pewarisan Nilai-nilai Kearifan Lokal untuk Memproteksi Masyarakat Bali dari Dampak Negatif Globalisasi. Journal of Bali Studies, 5(2). Retrieved from https://ojs.unud.ac.id/index.php/kajianbali/article/view/16775

Suwija, I. N. (2012). Nilai-nilai Pendidikan Karakter dalam Pembelajaran Bahasa Bali. Jurnal Pendidikan Karakter, 2(1). Retrieved from https://journal.uny.ac.id/index.php/jpka/article/view/1453/1240

Zongkai Yang, Qintang Liu. 2007. Research and Development of Web- Based Virtual online Clasroom. Jurnal Computer and Education48 (2007) 171-184 Available online at http://www.qou.edu/arabic/researchProgram/eLearningResearchs/researchDevelopment.pdf (C) Science direct.com Publishing doi:10.1016/j.compedu.2004.12.007 